\title{
Not a Third Party: Home State \\ Participation As a Matter of Right \\ in Investment Treaty Arbitration
}

\author{
Rebecca E. Khan
}

\section{Contents}

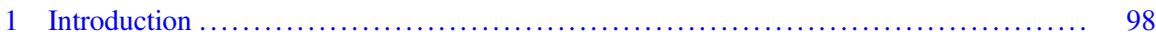

2 Diplomatic Protection: Why Non-disputing State Party Participation Is Problematic ..... 99

3 Comparison of Transparency Issues in Relation to Sovereign Respondents

and Non-disputing State Parties ....................................... 101

4 Non-disputing State Party Participation As Part of the Transparency Movement

in Investment Treaty Arbitration ........................................... 103

4.1 NAFTA and Non-disputing State Party Participation ...................... 103

4.2 ICSID and Non-disputing State Party Participation ........................... 104

4.3 UNCITRAL Transparency Rules and Non-disputing State Party Participation ..... 105

4.4 Survey of Investment Treaty Arbitration Cases with Non-disputing State Party

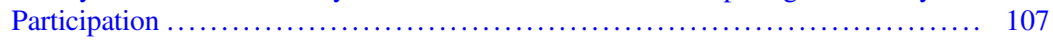

5 A Matter of Right: Non-disputing State Party Participation with Respect to Investment

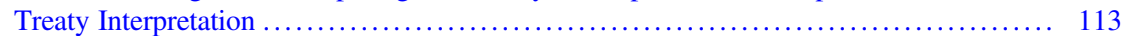

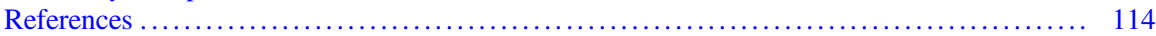

\begin{abstract}
Host states are not the only sovereign parties that an investment dispute can impact. The sovereign interests of an investor's home state are also potentially affected by an investment claim initiated by a national against an investment treaty partner, and more mechanisms should be put in place to ensure that the home state has access to the arbitration proceedings. This chapter argues for non-disputing state party participation as a matter of right in investment treaty arbitration cases. Whether or not the home state of the investor is informed of and allowed to participate in an investment dispute has largely been left to the discretion of arbitral tribunals; arbitration rules and jurisprudence have regarded the home state no differently than non-governmental third parties seeking to participate in the arbitration as amici curiae. From the perspective of increased transparency in the investor-state dispute settlement system, this chapter posits that non-disputing state parties must be accorded an elevated status in investor-state arbitration, with the following rights: first, to be formally notified at the outset about an investment treaty dispute; second,
\end{abstract}

\author{
R. E. Khan $(\bowtie)$ \\ University of the Philippines, College of Law, Manila, Philippines
}


to have access to the documents of the arbitration case; and, third, to make written submissions with respect to the interpretation of the international investment agreement invoked in the claim. The analysis begins by identifying the sovereign interests of the home state that come into play in an investment treaty arbitration. The perils of diplomatic protection are examined in this chapter, to provide the perspective from which to delimit the parameters for non-disputing state party participation. A survey of arbitration rules and jurisprudence outlines the level of participation thus far accorded to home states in investment treaty arbitration.

\section{Introduction}

State parties in investment disputes have transparency concerns that differ from those of investors. The home state of the investor is involved in an investment dispute not as a party to the arbitration proceedings but rather as the investment treaty partner of the host state, which is the sovereign respondent. The transparency concerns of the home state mirror those of the disputing state party rather than those of non-governmental non-parties that seek to participate as amici curiae in investment disputes. It is important to distinguish non-disputing state parties from non-sovereign entities that seek to intervene in investment disputes, and highlight that distinct sets of rules should apply to these entirely separate categories of non-parties.

The participation of non-disputing state parties in the investor-state dispute resolution process is relevant for the following reasons: first, the proposals and observations of the investor's home state during the treaty negotiation process are reflected in the travaux preparatoires of the relevant investment agreement; second, submissions in the form of amicus curiae briefs may be allowed by the investment arbitration tribunal with respect to issues of treaty interpretation; and, third, involvement of the home state would facilitate the enforcement of arbitral awards rendered in favour of its investors. ${ }^{1}$ This chapter focuses on the second type of participation. Issues regarding notification about ongoing investment treaty disputes will also be considered. Examining non-disputing state party participation from a transparency perspective, this chapter discusses diplomatic protection and its relationship to investor-state dispute settlement, then proceeds to canvass the existing parameters for non-disputing state party participation in investment treaty arbitration. Specifically, Sect. 2 considers why non-disputing state party participation was deemed problematic in the past, in view of the goal of the investor-state dispute settlement system to depoliticise investment arbitrations. Section 3 contrasts the transparency concerns of non-disputing state parties with those of sovereign respondents in investment disputes to demonstrate the need for participation by the investor's

\footnotetext{
${ }^{1}$ Malintoppi and Haeri (2016), p. 566.
} 
home state even though it has neither claims nor liabilities in the dispute. Section 4 reviews provisions in Chapter 11 of the North American Free Trade Agreement (NAFTA), the Arbitration Rules of the International Centre for Settlement of Investment Disputes (ICSID), and the United Nations Commission on International Trade Law (UNCITRAL) Rules on Transparency in Treaty-based Investor-State Arbitration (Transparency Rules) to highlight the importance of non-disputing state party participation in the transparency movement in investor-state dispute settlement. That section also surveys investment treaty arbitration cases where the sovereign respondent's treaty partners sought to intervene, demonstrating different outcomes in the case of such participation. Finally, Sect. 5 argues that non-disputing state party participation should be granted as a matter of right, rather than be subject to a tribunal's discretion, with respect to issues of interpretation of the relevant investment treaty.

\section{Diplomatic Protection: Why Non-disputing State Party Participation Is Problematic}

Diplomatic protection is highlighted in the UNCITRAL Transparency Rules as a danger when allowing submissions by the non-disputing treaty party. Article 5 of the UNCITRAL Transparency Rules emphasises "the need to avoid submissions which would support the claim of the investor in a manner tantamount to diplomatic protection." ${ }^{2}$ In a thought-provoking book chapter, Gabrielle Kaufmann-Kohler has cautioned that non-disputing state party submissions "pose risks that [non-governmental organisation] submissions do not raise." She points out that written submissions by an investor's home state should address matters of treaty interpretation only, because a submission by a home state containing case-specific factual arguments in support of its own national might already be tantamount to diplomatic protection. ${ }^{4}$ This sub-section explains why diplomatic protection is a concern in relation to submissions by the non-disputing state party.

Before the advent of investment treaty arbitration, diplomatic protection was the method by which a dispute between a state and a private party could be resolved. ${ }^{5}$ As succinctly summarised by Rudolf Dolzer and Christoph Schreuer:

Under traditional international law, investors did not have direct access to international remedies to pursue claims against foreign states for violation of their rights. They depended on diplomatic protection by their home states. A state exercising diplomatic protection espouses the claim of its national against another state and pursues it in its own name. ${ }^{6}$

\footnotetext{
${ }^{2}$ Article 5(2) of the UNCITRAL Transparency Rules.

${ }^{3}$ Kauffmann-Kohler (2013), p. 319.

${ }^{4}$ Kauffmann-Kohler (2013), p. 319.

${ }^{5}$ Reinisch and Malintoppi (2008), p. 712.

${ }^{6}$ Dolzer and Schreuer (2008), p. 211.
} 
Diplomatic protection is considered by some observers as a predecessor of investor-state dispute settlement. ${ }^{7}$ The creation of a mechanism giving investors direct recourse against host states without having to seek diplomatic protection from their home states was intended to depoliticise investment disputes, ${ }^{8}$ by bringing these disputes "within the realm of law rather than of politics and diplomacy." 9 With direct access to international arbitration against host states, investors have been freed from "the often politically motivated discretion of states whether or not to exercise diplomatic protection."

This objective of depoliticisation is embodied in an express prohibition on diplomatic protection contained in the 1965 Convention on the Settlement of Investment Disputes between States and Nationals of Other States, which established the International Centre for Settlement of Investment Disputes (ICSID Convention). Article 27 of the ICSID Convention provides as follows:

(1) No Contracting State shall give diplomatic protection, or bring an international claim, in respect of a dispute which one of its nationals and another Contracting State shall have consented to submit or shall have submitted to arbitration under this Convention, unless such other Contracting State shall have failed to abide by and comply with the award rendered in such dispute.

(2) Diplomatic protection, for the purposes of paragraph (1), shall not include informal diplomatic exchanges for the sole purpose of facilitating a settlement of the dispute.

The Case Concerning Barcelona Traction, Light and Power Company, Limited (Belgium v. Spain), decided by the International Court of Justice in $1970,{ }^{11}$ is often cited as a prime example of a state-to-state dispute that was initiated to resolve an investment claim. In that case, the Belgian Government stepped in to bring a claim on behalf of its nationals, who were shareholders in the Canadian company subject of the case, lodging a claim against Spain and seeking reparation for damage done to the Barcelona Traction, Light and Power Company by the Spanish government. ${ }^{12}$

The interests of a home state in espousing a claim of its nationals was viewed by the International Court of Justice as follows:

[T] he Belgian Government would be entitled to bring a claim if it could show that one of its rights had been infringed and that the acts complained of involved the breach of an international obligation arising out of a treaty or a general rule of law. The opinion has been expressed that a claim can accordingly be made when investments by a State's nationals abroad are thus prejudicially affected, and that since such investments are part of

\footnotetext{
${ }^{7}$ Kauffmann-Kohler (2013), p. 305, citing inter alia Juratowitch (2008), p. 10.

${ }^{8}$ Malintoppi and Haeri (2016), p. 565; Kauffmann-Kohler (2013), pp. 305-306.

${ }^{9}$ Kauffmann-Kohler (2013), p. 306.

${ }^{10}$ Reinisch (2015), p. 259.

${ }^{11}$ Barcelona Traction, Light and Power Company, Limited, Judgment, 5 February 1970, ICJ Reports 1970, p. 3.

${ }^{12}$ Barcelona Traction, Light and Power Company, Limited, Judgment, 5 February 1970, ICJ Reports 1970, p. 3, paras 1 et seq.
} 
a State's national economic resources, any prejudice to them directly involves the economic interest of the State. ${ }^{13}$

Bilateral (and multilateral) investment treaties now represent the protection extended by a home state over its nationals, achieved through the negotiation of these treaties to ensure that the rights of its citizens are protected abroad. States no longer have to espouse the claims of their nationals to seek redress from the state where the investment was made, since investors now have direct recourse against host states for investment treaty violations.

\section{Comparison of Transparency Issues in Relation to Sovereign Respondents and Non-disputing State Parties}

The transparency concerns of non-disputing state parties diverge to a certain degree from the concerns of sovereign respondents, and are generally limited to: first, the proper interpretation of the investment treaty pursuant to which the investment claim was filed and, second, the non-disputing state party's duties and obligations with respect to its nationals, claimants in the dispute.

Procedurally, the differences begin at the initiation of the investment claim. The requirements of due process dictate that host states named as respondents in investment claims are notified that a request for arbitration has been filed against them by an investor. ${ }^{14}$ By contrast, whether the home state of the investor of a pending claim is notified depends on the existence of provisions in the applicable investment treaty or specific arbitration rules mandating such notification, or if one of the parties voluntarily informs the non-disputing state party about the ongoing dispute. Neither the ICSID Convention nor the ICSID Arbitration Rules contain a specific provision mandating that the investor's home state should be notified of the initiation of an investment claim. (However, when ICSID registers a case, the names of the parties, as well as the particular investment treaty being invoked, are among the basic case information that is made publicly available.) ${ }^{15}$ Some treaties, however, provide for such notification, as well as the requirement to supply the non-disputing state party with the written submissions, transcripts, arbitral awards, and other documents produced during the arbitration proceedings. Notably, NAFTA and the Central American-Dominican Republic Free Trade Agreement (CAFTA-DR) contain provisions that direct the sovereign respondent to inform the non-disputing state parties that an investment claim has been filed, and to furnish the other state parties with

\footnotetext{
${ }^{13}$ Barcelona Traction, Light and Power Company, Limited, Judgment, 5 February 1970, ICJ Reports 1970, p.3, para. 86, emphasis added.

${ }^{14}$ Article 36(1) of the ICSID Convention.

${ }^{15}$ See https://icsid.worldbank.org/en/pages/cases/pendingCases.aspx?status=p.
} 
copies of submissions and awards, among others. ${ }^{16}$ The US model bilateral investment treaty (BIT) also contains a similar provision which has been adopted in some US BITs. ${ }^{17}$

The filing of an investment claim by one its nationals against one of its treaty partners can have a potential impact on the non-disputing state party, and more mechanisms should be put in place to ensure that the non-disputing state party has access to the proceedings and is informed about the case from the very beginning.

If the interpretation of provisions in the BITs is in issue, then the non-disputing state parties should be given every opportunity to present their views on interpretation, as the outcome of the arbitration proceeding with respect to these provisions has the potential to impact the interpretation of similar provisions in a state's BITs with other countries. An extended discussion in a separate section below argues that non-disputing state parties should be allowed — as a matter of right — to file written submissions on matters of treaty interpretation. ${ }^{18}$

Another aspect pointing to the necessity of providing information to the non-disputing party relates to allegations made in the course of the arbitral proceedings relating to the conduct of the home state's nationals in the host state. As will be discussed below, allegations of corruption in relation to the investment activity are becoming increasingly common in investment disputes (or, arguably, corruption has always been common, but is only now being highlighted as states use it as a jurisdictional defense). A non-disputing party may have an interest in monitoring the actions of its nationals abroad, especially if they involve criminal activity. One salient example embodying such a duty is the Foreign Corrupt Practices Act in the United States, which renders unlawful any bribery of foreign officials committed by US nationals abroad. ${ }^{19}$

\footnotetext{
${ }^{16}$ Article 1127 of NAFTA provides: "Notice - A disputing Party shall deliver to the other Parties: (a) written notice of a claim that has been submitted to arbitration no later than 30 days after the date that the claim is submitted; and (b) copies of all pleadings filed in the arbitration"; Article 10.21 ("Transparency of Arbitral Proceedings") of CAFTA-DR provides: "1. Subject to paragraphs 2 and 4 , the respondent shall, after receiving the following documents, promptly transmit them to the non-disputing Parties and make them available to the public: (a) the notice of intent; (b) the notice of arbitration; (c) pleadings, memorials, and briefs submitted to the tribunal by a disputing party and any written submissions submitted pursuant to Article 10.20.2 and 10.20.3 and Article 10.25; (d) minutes or transcripts of hearings of the tribunal, where available; and (e) orders, awards, and decisions of the tribunal."

${ }^{17}$ Article 29(1) ("Transparency of Arbitral Proceedings") of the 2012 US Model BIT, which replicates the 2004 version of this article, provides that "the respondent shall, after receiving the following documents, promptly transmit them to the non-disputing Party and make them available to the public: (a) the notice of intent; (b) the notice of arbitration; (c) pleadings, memorials, and briefs submitted to the tribunal by a disputing party and any written submissions submitted pursuant to Article 28(2) [Non-Disputing Party submissions] and (3) [Amicus Submissions] and Article 33 [Consolidation]; (d) minutes and transcripts of hearings of the tribunal, where available; and (e) orders, awards, and decisions of the tribunal." This provision appears as Article 29 of the 2005 US- Uruguay BIT; and Article 29 of the 2008 US-Rwanda BIT.

${ }^{18}$ See below Sect. 5 .

${ }^{19} 15$ USC $\S 78 d d-1$, et seq.
} 
An ongoing investment dispute has potential implications for the home state of the claimant investor with respect to various aspects of governance, and the non-disputing state party should be given access to the proceedings as a matter of routine.

\section{Non-disputing State Party Participation As Part of the Transparency Movement in Investment Treaty Arbitration}

This chapter examines international legal instruments designed specifically for investment treaty arbitration. It focuses on NAFTA Chapter 11, the ICSID Convention and 2006 Arbitration Rules, and the 2014 UNCITRAL Transparency Rules. A comparison of these three instruments reveals that there is as yet no uniform approach to dealing with the participation of non-disputing state parties. NAFTA expressly allows the practice but provides no guidelines, ICSID makes no distinction between non-state third parties and non-disputing state parties, while the UNCITRAL Transparency Rules devote an entire article to the matter.

\subsection{NAFTA and Non-disputing State Party Participation}

Article 1128 of NAFTA Chapter 11 provides: "On written notice to the disputing parties, a Party may make submissions to a Tribunal on a question of interpretation of this Agreement." The wording of this provision makes it clear that the non-disputing state parties have a right to be heard on an issue of NAFTA interpretation. $^{20}$ The scope of this provision notably does not extend towards addressing issues of fact. ${ }^{21}$ This treaty provision is crafted in a way that limits the participation of non-disputing state parties to issues of treaty interpretation.

Commentators have noted that Article 1128 provides no guidance or procedure to operationalise this provision. ${ }^{22}$ The rule does not mandate written submissions nor does it proscribe oral submissions. ${ }^{23}$ While the provision does not specifically provide for the right of a non-disputing state party to attend the oral hearings in the case, tribunals have generally allowed the presence of non-disputing state parties in NAFTA hearings. ${ }^{24}$ The right of non-disputing state parties is arguably implied in

\footnotetext{
${ }^{20}$ Kinnear (2005), p. 8.

${ }^{21}$ Bjorklund (2013), p. 517; Kinnear (2005), p. 8.

${ }^{22}$ Kinnear (2005), p. 8; Bjorklund (2013), p. 517.

${ }^{23}$ Kinnear (2005), p. 8; Bjorklund (2013), p. 518.

${ }^{24}$ Bjorklund (2013), pp. 517-518.
} 
the provision because to deny them the ability to apprise themselves of issues raised during the hearings would effectively render their participation right nugatory. ${ }^{25}$

\subsection{ICSID and Non-disputing State Party Participation}

As mentioned above, diplomatic protection is explicitly prohibited in the ICSID context. However, the ICSID Arbitration Rules concerning third-party submissions fail to draw clear parameters regarding the content of written submissions by non-disputing state parties. Rule 37(2) of the ICSID Arbitration Rules, which allows tribunals to accept written submissions by third parties, does not distinguish between non-disputing state parties and non-governmental organisations. As such, sub-paragraph "(a)" of that rule mandates the tribunal to consider the extent to which "the non-disputing party submission would assist the Tribunal in the determination of a factual or legal issue related to the proceeding". ${ }^{26}$ As already mentioned above, allowing a non-disputing state party to present arguments regarding the facts of a particular dispute, in support of its national investor, runs the risk of being de facto diplomatic protection. ${ }^{27}$ However, it may be argued that tribunals will construe Rule 37(2) with deference to Article 27 of the ICSID Convention. ${ }^{28}$

During the rule amendment process that led to the 2006 version of the ICSID Arbitration Rules, the initial proposal for Rule 37(2) was worded as allowing a "person or state" to make a written submission. ${ }^{29}$ However, some commentators considered this phrase too restrictive, so the current wording reads "person or entity". ${ }^{30}$ As a result of having one rule applicable to non-parties, whether sovereign or not, the ICSID Arbitration Rules in their current form, i.e. the 2006 version of the Rules, have no specific provision limiting the submissions of non-disputing state parties to matters of interpretation of the investment treaty. This is likely to change, however, in light of the ICSID rule amendment process launched in October $2016 .{ }^{31}$ As of February 2020, a draft provision entitled "Participation of Non-Disputing Treaty Party" appears as a proposed new provision of the ICSID Arbitration Rules. This draft rule provides:

Rule 68

Participation of Non-Disputing Treaty Party

(1) The Tribunal shall permit a Party to a treaty that is not a party to the dispute ("nondisputing Treaty Party") to make a written or oral submission on the interpretation

\footnotetext{
${ }^{25}$ Bjorklund (2013), p. 518.

${ }^{26}$ Rule 37(2)(a) of the ICSID Arbitration Rules, emphasis added.

${ }^{27}$ Kauffmann-Kohler (2013), p. 319.

${ }^{28}$ Kauffmann-Kohler (2013), p. 319.

${ }^{29}$ Obadia (2007), p. 368.

${ }^{30}$ Obadia (2007), p. 368.

${ }^{31}$ See https://icsid.worldbank.org/en/amendments/Pages/About/about.aspx.
} 
of the treaty at issue in the dispute and upon which consent to arbitration is based. The Tribunal may, after consulting with the parties, invite a non-disputing Treaty Party to make such a submission.

(2) The Tribunal shall ensure that non-disputing Treaty Party participation does not disrupt the proceeding or unduly burden or unfairly prejudice either party. To this end, the Tribunal may impose conditions on the filing of a written submission by the non-disputing Treaty Party, including with respect to the format, length or publication of the written submission and the time limit to file the submission.

(3) The parties shall have the right to make observations on the submission of the nondisputing Treaty Party. ${ }^{32}$

This draft article sets out to create distinct rules for the non-disputing state party by expressly allowing submissions on treaty interpretation and impliedly limiting participation to this aspect.

In a previous iteration of this amendment, however, the proposed text would have granted an ICSID arbitration tribunal the discretion to "allow a non-disputing Treaty Party to make a written submission on any other matter within the scope of the dispute," following the rules for non-sovereign third parties. ${ }^{33}$ This previous draft text, allowing submissions to matters beyond treaty interpretation, is similar to the provision in the 2014 UNCITRAL Transparency Rules, discussed below. However, this text was deleted in subsequent drafts. ${ }^{34}$ Thus, the forthcoming amendment to the ICSID Arbitration Rules hews closely to the NAFTA text discussed above.

\subsection{UNCITRAL Transparency Rules and Non-disputing State Party Participation}

The imprecision of Rule 37(2) of the 2006 ICSID Arbitration Rules may have inspired the drafters of the UNCITRAL Transparency Rules to create separate rules for third-party participation by non-governmental entities and non-disputing state parties. Article 4 of the UNCITRAL Transparency Rules governs "Submission by a third person", referring to "a person that is not a disputing party, and not a non-disputing Party to the treaty." 35 Meanwhile, Article 5 governs "Submission by a non-disputing Party to the treaty". Accordingly:

\footnotetext{
${ }^{32}$ ICSID Secretariat (February 2020) https://icsid.worldbank.org/en/Documents/WP_4_Vol_1_En. pdf, p. 68.

${ }^{33}$ ICSID Secretariat (2 August 2018) https://icsid.worldbank.org/en/Documents/III.Amendments_ Vol_3_AR.pdf, pp. 217-218.

${ }^{34}$ ICSID Secretariat (March 2019) https://icsid.worldbank.org/en/Documents/Vol_1.pdf, pp. 275-276.

${ }^{35}$ Article 4(1) of the UNCITRAL Transparency Rules.
} 
1. The arbitral tribunal shall, subject to paragraph 4, allow, or, after consultation with the disputing parties, may invite, submissions on issues of treaty interpretation from a non-disputing Party to the treaty.

2. The arbitral tribunal, after consultation with the disputing parties, may allow submissions on further matters within the scope of the dispute from a non-disputing Party to the treaty. In determining whether to allow such submissions, the arbitral tribunal shall take into consideration, among other factors it determines to be relevant, the factors referred to in article 4, paragraph 3, and, for greater certainty, the need to avoid submissions which would support the claim of the investor in a manner tantamount to diplomatic protection.

3. The arbitral tribunal shall not draw any inference from the absence of any submission or response to any invitation pursuant to paragraphs 1 or 2 .

4. The arbitral tribunal shall ensure that any submission does not disrupt or unduly burden the arbitral proceedings, or unfairly prejudice any disputing party.

5. The arbitral tribunal shall ensure that the disputing parties are given a reasonable opportunity to present their observations on any submission by a non-disputing Party to the treaty. ${ }^{36}$

A reading of the above provision reveals that the UNCITRAL Transparency Rules contemplate two types of submissions by non-disputing state parties: first, submissions on issues of treaty interpretation and, second, submissions on matters within the scope of the dispute. The first type of submission is treated as a matter of right in Article 5(1), with the use of the word "shall". Acceptance of a submission by a non-disputing state party is required when requested by that non-disputing state party. The second part of Article 5(1) contemplates inviting the non-disputing state party to make a submission when it has not sought such participation motu proprio. In the latter scenario, the UNCITRAL Transparency Rules instruct the tribunal to consult the disputing parties before extending such an invitation.

The second type of submission, provided in Article 5(2), gives the tribunal the discretion to accept submissions relating to other issues. Using the language "matters within the scope of the dispute", this provision appears to be an attempt to place non-disputing state parties on an equal footing with the non-disputing parties covered by Article 4, and also makes a cross-reference to the factors listed in Article 4(3). Highlighting a significant difference between the non-parties contemplated in Articles 4 and 5, the provision also cautions tribunals about submissions by a non-disputing state party that may rise to the level of diplomatic protection. ${ }^{37}$

\footnotetext{
${ }^{36}$ Article 5 of the UNCITRAL Transparency Rules.

${ }^{37}$ Article 5(2) of the UNCITRAL Transparency Rules.
} 


\subsection{Survey of Investment Treaty Arbitration Cases with Non-disputing State Party Participation}

NAFTA cases have seen relatively active participation of non-disputing state parties because of the express provision allowing their participation. ${ }^{38}$ This level of participation by home states has not been as prevalent in the wider universe of investment disputes initiated pursuant to investment treaties. ${ }^{39}$ Explicit clauses regarding non-disputing state party participation do exist in investment treaties, ${ }^{40}$ primarily in the investment chapters of free trade agreements (FTAs) entered into by the United States, ${ }^{41}$ but such provisions have yet to become standard features of BITs. ${ }^{42}$ As will be discussed below, the lack of explicit guidance from treaty provisions led to different consequences with respect to non-disputing state party participation.

What follows are three examples where the non-disputing state party provided comments on the proper interpretation of the BIT invoked in the dispute. Each case presents a unique scenario as to the timing of the interventions, the party that initiated the involvement of the non-disputing state party, and the outcome of the non-disputing state party's participation.

\footnotetext{
${ }^{38}$ Article 1128 of NAFTA.

${ }^{39}$ Two examples of non-disputing state party participation pursuant to express treaty provisions are: the written submission by the United States in Adel A Hamadi Al Tamimi v. Oman (ICSID Case No. ARB/11/33), pursuant to Article 10.19 .2 of the 2006 US-Oman free trade agreement (FTA); and the written submission by Canada in Bear Creek Mining Corporation v. Peru (ICSID Case No. ARB/14/21), pursuant to Article 832.1 of the 2008 Canada-Peru FTA. Worthy of note is that these non-disputing state parties are also members of NAFTA.

${ }^{40}$ Ishikawa (2015), p. 147.

${ }^{41}$ A clause providing that "[t]he non-disputing Party may make oral and written submissions to the tribunal regarding the interpretation of this Agreement" makes an appearance, inter alia, in the following treaties: Article 11.20.4 of the 2007 US-Korea FTA; Article 10.19.2 of the 2006 US-Oman FTA; Article 10.19.2 of the 2004 Morocco-US FTA; Article 10.19.2 of the 2003 US-Chile FTA.

${ }^{42}$ Aside from US FTAs, other examples include: Article 86 of the 2005 Agreement between Japan and the Mexico for the Strengthening of Economic Partnership, which provides: "On written notice to the disputing parties, the Party other than the disputing Party may make submissions to a Tribunal on a question of interpretation of this Agreement"; and Article 832.1 of the 2008 Canada-Peru FTA, which provides: "On written notice to the disputing parties, the non-disputing Party may make submissions to a Tribunal on a question of interpretation of this Agreement." Considering that the examples outside of NAFTA are treaties entered into by the United States of America, Mexico, and Canada, it can be reasonably inferred that the existence of these provisions is a direct influence of the NAFTA experience.
} 


\subsubsection{Aguas del Tunari v. Bolivia}

Aguas del Tunari v. Bolivia was initiated in 2002 pursuant to the 1992 NetherlandsBolivia BIT. ${ }^{43}$ Aguas del Tunari identified itself as "a legal person constituted in accordance with the laws of Bolivia", that could bring a claim pursuant to the Netherlands-Bolivia BIT because it was "controlled directly or indirectly by nationals of the Netherlands". ${ }^{44}$ Referring to two entities incorporated under Dutch law that owned shares in a Luxembourg corporation which directly owned $55 \%$ of the shares in Aguas del Tunari, ${ }^{45}$ the claimant argued that the corporate structure of the Bolivian sociedad anónima made it a national of the Netherlands, in accordance with the BIT. ${ }^{46}$ This was the basis for the claimant's assertions that the ICSID tribunal had jurisdiction over the dispute. For its part, Bolivia presented objections to the tribunal's jurisdiction, arguing primarily that Bolivia did not consent to the jurisdiction of ICSID. ${ }^{47}$ The sovereign respondent also argued that Aguas del Tunari was not a national of the Netherlands within the meaning of the BIT, since it was not "controlled directly or indirectly" by Dutch nationals. ${ }^{48}$

The interpretation of the BIT was at the crux of all issues presented by the parties in the jurisdictional phase of the arbitration. The claimant introduced in the proceedings written exchanges between members of the legislative and executive branches of the Dutch government, with the former seeking a response from the latter on the question of whether multinational corporations could invoke the BIT. ${ }^{49}$ On the one hand, the claimant's expert witness argued that the intragovernmental communications contradicted each other and indicated "confusion as to the facts." The sovereign respondent, on the other hand, seized upon these documents introduced by the claimant to argue that the interpretation of the Government of the Netherlands about who can invoke the BIT was the same as its own interpretation,

\footnotetext{
${ }^{43}$ Aguas del Tunari v. Bolivia, ICSID Case No. ARB/02/3, Decision on Respondent's Objections to Jurisdiction, 21 October 2005, para. 79.

${ }^{44}$ Aguas del Tunari v. Bolivia, ICSID Case No. ARB/02/3, Decision on Respondent's Objections to Jurisdiction, 21 October 2005, para. 81, cf. para. 80. One of the provisions defining "nationals" that could bring a claim under the BIT enumerated "legal persons controlled directly or indirectly, by nationals of that Contracting Party, but constituted in accordance with the law of the other Contracting Party."

${ }^{45}$ Aguas del Tunari v. Bolivia, ICSID Case No. ARB/02/3, Decision on Respondent's Objections to Jurisdiction, 21 October 2005, paras 70-72, cf. para. 81.

${ }^{46}$ Aguas del Tunari v. Bolivia, ICSID Case No. ARB/02/3, Decision on Respondent's Objections to Jurisdiction, 21 October 2005, para. 82.

${ }^{47}$ Aguas del Tunari v. Bolivia, ICSID Case No. ARB/02/3, Decision on Respondent's Objections to Jurisdiction, 21 October 2005, para. 84.

${ }^{48}$ Aguas del Tunari v. Bolivia, ICSID Case No. ARB/02/3, Decision on Respondent's Objections to Jurisdiction, 21 October 2005, para. 85.

${ }^{49}$ Aguas del Tunari v. Bolivia, ICSID Case No. ARB/02/3, Decision on Respondent's Objections to Jurisdiction, 21 October 2005, paras 252-257.

${ }^{50}$ Aguas del Tunari v. Bolivia, ICSID Case No. ARB/02/3, Decision on Respondent's Objections to Jurisdiction, 21 October 2005, para. 256.
} 
such that both state parties to the treaty "are on record as saying that [the BIT] does not apply to this case."

In its Decision on Respondent's Objections to Jurisdiction, the tribunal devoted a considerable part of the discussion to a "unique aspect of this proceeding, namely its consideration of the relevance of several statements of the Netherlands, the non-disputing state party to the BIT." ${ }^{, 52}$ The tribunal decided to reach out to the non-disputing state party for further elucidation on the disputed intra-governmental communications. In a 2004 letter, described by the tribunal in its decision as "the first inquiry of a non-disputing State Party to a BIT", the tribunal addressed the Legal Advisor of the Foreign Ministry of the Netherlands "to secure the comments of the Netherlands as to specific documentary bases for written responses which the Dutch government provided to parliamentary questions." 53 Kaufmann-Kohler notes that the tribunal "was mindful not to trigger the Netherlands' diplomatic protection" by using specific language to that effect and highlighting Article 27 of the ICSID Convention. $^{54}$

The tribunal also delineated the parameters of the reply sought from the Netherlands as a non-disputing state party. It wrote in its letter:

Given that the Government of the Netherlands is not a party or otherwise present in this arbitration, the Tribunal concludes that information from the Government of the Netherlands would assist the work of the Tribunal. Given further the above quoted Article 27 of the ICSID Convention and the fact that the Netherlands is not a party to this arbitration, the Tribunal is also of the view that such questions must be specific and narrowly tailored, aimed at obtaining information supporting interpretative positions of general application rather than ones related to a specific case. ${ }^{55}$

The Netherlands replied through the Legal Advisor of the Foreign Ministry with a cover letter describing the intra-governmental communications as "based on information from the press" which "may not necessarily have been correct". 56 Attached

\footnotetext{
${ }^{51}$ Aguas del Tunari v. Bolivia, ICSID Case No. ARB/02/3, Decision on Respondent's Objections to Jurisdiction, 21 October 2005, para. 249.

${ }^{52}$ Aguas del Tunari v. Bolivia, ICSID Case No. ARB/02/3, Decision on Respondent's Objections to Jurisdiction, 21 October 2005, para. 248.

${ }^{53}$ Aguas del Tunari v. Bolivia, ICSID Case No. ARB/02/3, Decision on Respondent's Objections to Jurisdiction, 21 October 2005, para. 258.

${ }^{54}$ Kauffmann-Kohler (2013), p. 314. The letter sent by the tribunal was quoted in its 2005 Decision on Jurisdiction, at para. 258. With respect to diplomatic protection, the tribunal wrote: "The Tribunal recognizes the obligation of the Netherlands under [Article 27 of] the ICSID Convention to not provide diplomatic protection to its nationals in the case of investment disputes covered by the Convention. In this sense, the Tribunal wishes to emphasize that it does not seek the view of the Netherlands as to the Tribunal's jurisdiction in this matter, rather it seeks only to secure the comments of the Netherlands as to specific documentary bases for written responses which the Dutch government provided to parliamentary questions."

${ }^{55}$ Aguas del Tunari v. Bolivia, ICSID Case No. ARB/02/3, Decision on Respondent's Objections to Jurisdiction, 21 October 2005, para. 258, emphasis added.

${ }^{56}$ Aguas del Tunari v. Bolivia, ICSID Case No. ARB/02/3, Decision on Respondent's Objections to Jurisdiction, 21 October 2005, para. 261.
} 
was a 1992 document entitled "Interpretation of the Agreement on encouragement and reciprocal protection of investments between the Kingdom of the Netherlands and the Republic of Bolivia." 57 Ultimately, the tribunal concluded that the Dutch response provided no additional information that would be relevant to shed light on the "general interpretative position" of the Netherlands on the BIT provisions at issue. $^{58}$

\subsubsection{CME v. Czech Republic}

CME Czech Republic v. the Czech Republic was an UNCITRAL arbitration initiated in 2000 by a Dutch corporation pursuant to the 1991 Netherlands-Czech Republic BIT. ${ }^{59}$ In 2001, the tribunal issued a Partial Award finding the sovereign respondent liable for violations of the BIT. ${ }^{60}$ After the issuance of this Partial Award, the Czech Republic called for consultations with the Netherlands, pursuant to Article 9 of the BIT. ${ }^{61}$ This treaty provision allows either state party to "propose [to] the other Party to consult on any matter concerning the interpretation or application" of the BIT. ${ }^{62}$ The Czech Government expressed "its concern over a number of aspects of the Partial Award which were in its view inconsistent with the Treaty." ${ }^{\text {"63 }}$ Specifically, the Czech Republic sought to consult with the Netherlands regarding the correct interpretation of the BIT provision which specifies the applicable law for resolving an investment dispute; ${ }^{64}$ the assignment of claims arising under the BIT; ${ }^{65}$ and the application of the BIT to investment disputes which had previously been raised by an indirect holder of the same investment of a different nationality under a comparable BIT. 66

\footnotetext{
${ }^{57}$ Aguas del Tunari v. Bolivia, ICSID Case No. ARB/02/3, Decision on Respondent's Objections to Jurisdiction, 21 October 2005, para. 259.

${ }^{58}$ Aguas del Tunari v. Bolivia, ICSID Case No. ARB/02/3, Decision on Respondent's Objections to Jurisdiction, 21 October 2005, para. 262.

${ }^{59}$ CME v. Czech Republic, Final Award, 14 March 2003, paras 1-3. In para. 3, state succession is clarified: "The Treaty entered into force in the Czech and Slovak Federal Republic on October 1, 1992 and, after the Czech and Slovak Federal Republic ceased to exist on December 31, 1992, the Czech Republic succeeded to the rights and obligations of the Czech and Slovak Federal Republic under the Treaty".

${ }^{60}$ CME v. Czech Republic, Partial Award, 13 September 2001, para. 624.

${ }^{61}$ CME v. Czech Republic, Final Award, 14 March 2003, para. 87.

${ }^{62}$ Article 9 of the Netherlands-Czech and Slovak Federal Republic BIT (1991).

${ }^{63}$ CME v. Czech Republic, Final Award, 14 March 2003, para. 87.

${ }^{64}$ CME v. Czech Republic, Final Award, 14 March 2003, paras. 88, 91, 218, 398.

${ }^{65}$ CME v. Czech Republic, Final Award, 14 March 2003, paras. 88, 92, 220-224.

${ }^{66}$ CME v. Czech Republic, Final Award, 14 March 2003, paras. 88, 93. On this third point, note that the CME v. Czech Republic case is often discussed in relation to parallel proceedings in investment arbitration, since the UNCITRAL case of Ronald S. Lauder v. Czech Republic was brought concerning the same investment but under the Czech Republic-US BIT.
} 
After a series of meetings between representatives of the Czech and Dutch Governments, their "Common Positions" on these three issues were recorded in the Agreed Minutes, dated 1 July 2002. ${ }^{67}$ In providing these minutes to the tribunal, the sovereign respondent put forward the view that the common positions of the contracting state parties to the BIT should bind the tribunal for the issues they covered. The tribunal summarised the Czech Republic's position as follows:

The Respondent's position in respect to the agreed minutes on the Common Position of the delegates of The Netherlands and the Czech Republic is that the two contracting States reserved to themselves the exclusive competence to decide on how the Treaty should be interpreted and applied. The Tribunal has not more competence to state how the Treaty shall be interpreted and applied than any one of the State parties unilaterally. To the extent that a tribunal makes an incorrect interpretation or misapplies the Treaty, the States parties can overrule the tribunal's mistake. [...]

The common positions, representing the interpretations and application of the Treaty agreed between its contracting parties, are conclusive and binding on the Tribunal. ${ }^{68}$

In the Final Award, however, the tribunal did not elucidate how much deference, if any, should be accorded to the common positions agreed upon by the state parties with respect to the interpretation of the treaty provisions at issue. Instead, the tribunal indicated that the common positions "support[ed] the Tribunal's view" with respect to one issue, 69 "confirm[ed]" the tribunal's analysis with respect to another, ${ }^{70}$ and were contrary to the respondent's position on a third issue. ${ }^{71}$ In refraining from using the common positions as a source of interpretation and in using it instead as a reference point to either support or confirm its reasoning, the tribunal appeared to assert its own analysis over that of the contracting parties to the BIT, without explaining to what extent it paid attention to the common positions.

\subsubsection{SGS v. Pakistan}

SGS Société Générale de Surveillance v. Pakistan was an ICSID case initiated in 2001 pursuant to the Switzerland-Pakistan BIT. ${ }^{72}$ This case is significant because it is one of the first times that an investment arbitration tribunal had to consider an umbrella clause in a BIT. ${ }^{73}$ In its Decision on Objections to Jurisdiction, the tribunal rejected the claimant's argument that Article 11 of the Switzerland-Pakistan BIT

\footnotetext{
${ }^{67}$ CME v. Czech Republic, Final Award, 14 March 2003, para. 89.

${ }^{68}$ CME v. Czech Republic, Final Award, 14 March 2003, paras 216-217, emphasis added.

${ }^{69}$ CME v. Czech Republic, Final Award, 14 March 2003, para. 437.

${ }^{70}$ CME v. Czech Republic, Final Award, 14 March 2003, para. 400.

${ }^{71}$ CME v. Czech Republic, Final Award, 14 March 2003, para. 504.

${ }^{72} S G S$ v. Pakistan, ICSID Case No. ARB/01/13, Decision of the Tribunal on Objections to Jurisdiction, 6 August 2003, para. 2.

${ }^{73}$ SGS v. Pakistan, ICSID Case No. ARB/01/13, Decision of the Tribunal on Objections to Jurisdiction, 6 August 2003, para. 164; Yannaca-Small (2006), pp. 15-16.
} 
elevated breaches of a contract to the status of breaches of the investment treaty. ${ }^{74}$ The tribunal ultimately ruled that, although it had jurisdiction over SGS's claims pursuant to the BIT, it did not have jurisdiction over claims based on breaches of contractual commitments in a "pre-shipment inspection agreement" signed between SGS and Pakistan. ${ }^{75}$ In its analysis of the proper interpretation of Article 11 of the BIT, the tribunal noted that it had taken into account Pakistan's views and faulted the claimant for not submitting evidence about Switzerland's interpretation of the provision that would support its position:

The Tribunal is not saying that States may not agree with each other in a BIT that henceforth, all breaches of each State's contracts with investors of the other State are forthwith converted into and to be treated as breaches of the BIT. What the Tribunal is stressing is that in this case, there is no clear and persuasive evidence that such was in fact the intention of both Switzerland and Pakistan in adopting Article 11 of the BIT. Pakistan for its part in effect denies that, in concluding the BIT, it had any such intention. SGS, of course, does not speak for Switzerland. But it has not submitted evidence of the necessary level of specificity and explicitness of text. We believe and so hold that, in the circumstances of this case, SGS's claim about Article 11 of the BIT must be rejected. ${ }^{76}$

After the publication of this decision, the Swiss Government sent a letter to ICSID to express its disagreement with the tribunal's "very narrow interpretation" of the umbrella clause provided in Article 11 of the Switzerland-Pakistan BIT, and explaining the state's intentions upon entering the treaty. ${ }^{77}$ The letter from the Swiss authorities inquired as to "why the Tribunal has not found it necessary to enquire about their view on the meaning of Article 11 in spite of the fact that the Tribunal attributed considerable importance to the intent of the Contracting Parties in drafting this Article and indeed put this question to one of the Contracting Parties (Pakistan)."78 The letter from the Swiss Government also strongly expressed its dismay at the tribunal's interpretation: "the Swiss authorities are alarmed about the very narrow interpretation given to the meaning of Article 11 by the Tribunal, which not only runs counter to the intention of Switzerland when concluding the Treaty but is quite evidently neither supported by the meaning of similar articles in BITs concluded by other countries nor by academic comments on such provisions."79

\footnotetext{
${ }^{74} S G S$ v. Pakistan, ICSID Case No. ARB/01/13, Decision of the Tribunal on Objections to Jurisdiction, 6 August 2003, para. 166. Article 11 of the Switzerland-Pakistan BIT declares: "Either Contracting Party shall constantly guarantee the observance of the commitments it has entered into with respect to the investments of the investors of the other Contracting Party."

${ }^{75} S G S$ v. Pakistan, ICSID Case No. ARB/01/13, Decision of the Tribunal on Objections to Jurisdiction, 6 August 2003, para. 190.

${ }^{76} S G S$ v. Pakistan, ICSID Case No. ARB/01/13, Decision of the Tribunal on Objections to Jurisdiction, 6 August 2003, para. 173, emphasis added.

${ }^{77}$ Kauffmann-Kohler (2013), p. 315; Yannaca-Small (2006), pp. 15-16.

${ }^{78}$ Kauffmann-Kohler (2013), p. 315.

${ }^{79}$ Malintoppi and Haeri (2016), p. 576.
} 
However, since this letter was a reaction to the already-rendered jurisdictional decision, it had no influence on the outcome of the case. ${ }^{80}$

\section{A Matter of Right: Non-disputing State Party Participation with Respect to Investment Treaty Interpretation}

Non-party participation is a key aspect of transparency. The cases discussed in the previous section demonstrate the different outcomes for non-disputing state parties. In Aguas del Tunari v. Bolivia, the tribunal initiated communication to the non-disputing state party to seek clarificatory comments regarding intragovernmental communications on treaty provisions. In CME v. the Czech Republic, the sovereign respondent sought consultations with its treaty partner, but it is unclear what deference, if any, the tribunal accorded to the common positions of the treaty parties. In $S G S v$. Pakistan, the non-disputing state party was effectively excluded from the proceedings by not being informed, and thus did not have the opportunity to participate. The inconsistent jurisprudence and arbitral practice reveal that there is a long way to go in order to establish non-disputing state party participation as a right of the sovereign respondent's investment treaty partner.

Meg Kinnear presents three key reasons why non-disputing state parties should be allowed to participate in investment treaty disputes. First, as parties to the treaty being interpreted, "these states have the experience of having negotiated the treaty and have a unique perspective on how the treaty should be interpreted." 81 Eloïse Obadia similarly points out that a non-disputing state party could file submissions "concerning the treaty's travaux préparatoires and the interpretation of the treaty's provisions in relation to jurisdictional matters." ${ }^{, 82}$ A second reason is that non-disputing state parties, as parties to the investment treaty, are also potential respondents in future disputes under that treaty. "States thus may be subject to numerous challenges and will be living with and interpreting the treaty obligations at issue in numerous contexts for many years to come." ${ }^{, 83}$ Finally, the interest of the non-disputing state party vis-à-vis the investment treaty invoked in the dispute is congruent with that of the sovereign respondent:

[A] State Parties' interest in disputes is not just defensive. Rather, States have compelling interest to ensure that an investment treaty actually provides investor protection and promotes foreign investment in the host State. Investment protection and promotion is the raison d'être for States' entrance into such treaties and thus States have an interest in seeing that BITs are interpreted coherently, logically and consistently. Consistency in BIT

\footnotetext{
${ }^{80}$ Kauffmann-Kohler (2013), p. 315.

${ }^{81}$ Kinnear (2005), p. 8.

${ }^{82}$ Obadia (2007), p. 368.

${ }^{83}$ Kinnear (2005), p. 8.
} 
interpretation is especially key because there is no formal system of stare decisis or precedent within this treaty regime. The credibility of the entire investor-State dispute settlement system is undermined when irreconcilable decisions are issued. [...] State party participation is one way that States can ensure cohesive jurisprudence and the continued integrity of the arbitral system. ${ }^{84}$

Just as the doors have opened for non-governmental organisations to participate as amici curiae in investor-state disputes, so too must participation by non-disputing state parties have started to become an established norm in investment treaty cases. This can be further achieved by establishing investment arbitration rules that explicitly mandate notification of disputes to home states and allow non-disputing state party submissions, even when the applicable investment treaty does not contain an express provision regarding non-disputing state party participation. Transparency must be inclusive for all actors in the investor-state dispute settlement system, and there are cogent reasons to support the participation of non-disputing state parties as a matter of right with respect to issues of treaty interpretation, instead of regarding such participation as subject to the discretion of an investment arbitration tribunal.

\section{References}

Bjorklund A (2013) NAFTA Chapter 11. In: Brown C (ed) Commentaries on selected model investment treaties. Oxford University Press, Oxford, pp 465-532

Dolzer R, Schreuer C (2008) Principles of international investment law. Oxford University Press, Oxford

ICSID Secretariat (August 2018) Proposals for amendment of the ICSID rules - working paper. https://icsid.worldbank.org/en/Documents/III.Amendments_Vol_3_AR.pdf

ICSID Secretariat (March 2019) Proposals for amendment of the ICSID rules - working paper \#2. https://icsid.worldbank.org/en/Documents/Vol_1.pdf

ICSID Secretariat (February 2020) Proposals for the amendment of the ICSID rules, ICSID Working Paper \#4. https://icsid.worldbank.org/en/Documents/WP_4_Vol_1_En.pdf

Ishikawa $T$ (2015) Keeping interpretation in investment treaty arbitration 'on Track': the role of state parties. In: Kalicki J, Joubin-Bret A (eds) Reshaping the investor-state dispute settlement system. Brill Nijhoff, Leiden, pp 115-149

Juratowitch B (2008) The relationship between diplomatic protection and investment treaties. ICSID Rev Foreign Invest Law J 23(1):10

Kauffmann-Kohler G (2013) Non-disputing state submissions in investment arbitration: resurgence of diplomatic protection? In: de Chazournes LB et al (eds) Diplomatic and judicial means of dispute settlement. Martinus Nijhoff, Leiden, pp 307-326

Kinnear M (2005) Transparency and third party participation in investor-state dispute settlement http://www.oecd.org/investment/internationalinvestmentagreements/36979626.pdf

Malintoppi L, Haeri H (2016) The non-disputing state party in investment arbitration: an interested player or the third man out? In: Caron D et al (eds) Practising virtue: inside international arbitration. Oxford University Press, Oxford, pp 565-583

Obadia E (2007) Extension of proceedings beyond the original parties: non-disputing party participation in investment arbitration. ICSID Rev Foreign Invest Law J 22:349-379

\footnotetext{
${ }^{84}$ Kinnear (2005), p. 8.
} 
Reinisch A (2015) Investors. In: Noortmann M et al (eds) Non-state actors in international law. Hart Publishing, Oxford, pp 253-271

Reinisch A, Malintoppi L (2008) Methods of dispute resolution. In: Muchlinski P et al (eds) The Oxford handbook of international investment law. Oxford University Press, Oxford, pp 691-720

Yannaca-Small K (2006) Interpretation of the umbrella clause in investment agreements. OECD Working Papers on International Investment, 2006/03. OECD Publishing, Paris. https://doi.org/ $10.1787 / 415453814578$

Rebecca E. Khan is head of arbitration and international dispute resolution at the Manila-based law firm Disini Law. She teaches international investment law, and government contract law in the Master of Laws (LLM) programme of the University of the Philippines-College of Law, and is an Associate Professor in the Juris Doctor (JD) programme at the De La Salle University-College of Law. Her writing in the area of international arbitration has been published as book chapters in Europe, the United States, and the Philippines. She holds a Doctor of Juridical Science (SJD) degree, summa cum laude, from the Central European University in Budapest. She was a visiting scholar at the Max Planck Institute for Comparative Public Law and International Law in Heidelberg. As a Fulbright scholar, she obtained her LLM in International and Comparative Law, with highest honors, from the George Washington University in Washington, DC. Formerly a government attorney, her international litigation experience includes arbitrations before the International Centre for Settlement of Investment Disputes (ICSID) and the International Chamber of Commerce (ICC), as well as disputes brought before the World Trade Organization (WTO). She was appointed by the Philippine Supreme Court to its drafting committee for the Special Rules of Court on Alternative Dispute Resolution. Rebecca was also part of the Philippine delegation to UNCITRAL during the drafting of the Rules on Transparency in Treaty-based Investor-State Arbitration.

Open Access This chapter is licensed under the terms of the Creative Commons Attribution 4.0 International License (http://creativecommons.org/licenses/by/4.0/), which permits use, sharing, adaptation, distribution and reproduction in any medium or format, as long as you give appropriate credit to the original author(s) and the source, provide a link to the Creative Commons license and indicate if changes were made.

The images or other third party material in this chapter are included in the chapter's Creative Commons license, unless indicated otherwise in a credit line to the material. If material is not included in the chapter's Creative Commons license and your intended use is not permitted by statutory regulation or exceeds the permitted use, you will need to obtain permission directly from the copyright holder.

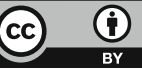

